\title{
An Evaluation of Hand Dominancy and its Relationship with Hand involvement and hand Dexterity in Patients with Rheumatoid Arthritis
}

\author{
Romatoid Artritli Hastalarda El Dominansisi ile El Tutulumu ve Becerisi Arasındaki \\ İlişkinin Değerlendirilmesi
}

\begin{abstract}
Ebru UMAY, Alev ÇEVİKOL, Aytül ÇAKCI
Department of Physical Medicine and Rehabilitation, Ankara Dışkapı Yıldırım Beyazıt Training and Research Hospital, Ankara, Turkey
\end{abstract}

Objectives: This study aims to evaluate whether hand dominancy in patients with rheumatoid arthritis (RA) using their right hand dominantly is associated with clinical and radiological involvement of the hand and hand dexterity.

Patients and methods: Two hundred and forty-nine patients (238 females, 11 males; mean age 53.0 \pm 11.8 years; range 25 to 78 years) with right-hand dominance were included in this study. In the evaluation of hand and wrist involvement in the patients, the range of motion (ROM) of the wrist, metacarpophalangeal joints (MCPJs) and proximal interphalangeal joints (PIPJs) were measured and the presence of deformities and tenosynovitis was recorded. Hand dexterity was assessed using the nine hole peg test, hand grip capacity (six types), and grip strength. The Larsen score was calculated, the results were compared between two hands.

Results: Range of motion limitation in wrist flexion, extension and total number of PIPJs, piano key sign, and boutonniere deformity were more common in the dominant (right) hand. The right hand was stronger than the left; however, there was no difference between the hands in terms of their grip types. The radiological findings of the right hand were more destructive than those of the left hand.

Conclusion: Our study results suggest that patients with RA have a higher incidence of joint limitation and radiological damage in the dominant hand and some deformities can be observed more frequently in the dominant hand. However, the dominant hand is still stronger than the non-dominant hand.

Key words: Dominancy; grip strength; hand; joint involvement; rheumatoid arthritis.
Amaç: Çalışmamızda sağ elini dominant olarak kullanan romatoid artritli (RA) hastalarda el dominansisi ile klinik ve radyolojik olarak el tutulumu ve el becerisi arasında ilişki olup olmadığının değerlendirilmesi amaçlandı.

Hastalar ve yöntemler: Çalışmaya sağ elini dominant olarak kullanan 249 hasta (238 kadın,

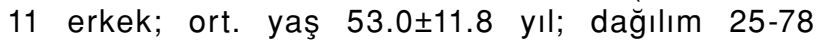
yıl) alındı. Hastaların el ve el bileği tutulumunun değerlendirilmesinde, el ve el bileği eklem hareket açıklığı (EHA), metakarpofalangeal eklemler (MKFE) ve proksimal interfalangeal eklemler (PIFE) ölçüldü ve deformitelerin ve tenosinovitin varlığı kaydedildi. El becerisi nine hole peg testi, el kavrama kapasitesi (altı tip) ve kaba kavrama kuvveti ile değerlendirildi. Larsen skoru hesaplandı ve sonuçlar iki el arasında kıyaslandı.

Bulgular: El bilek fleksiyon, ekstansiyon ve total PIFE EHA kısıtlılığı, piyano tuşu belirtisi ve düğme iliği deformitesi varlığı dominant (sağ) elde daha fazla idi. Sağ el sol ele göre daha kuvvetli bulundu, fakat iki el arasında kavrama tipleri açısından farklılık saptanmadı. Sağ elin radyolojik bulguları sol ele göre daha destrüktif idi.

Sonuç: Çalışma bulgularımıza göre, RA'lı hastaların dominant eli daha fazla eklem kısıtlılığı ve radyolojik hasar içermekte idi, ayrıca bazı deformiteler dominant elde daha fazla gözlenebilmekte idi. Ancak, bu sonuçlara rağmen, dominant el halen dominant olmayan elden daha kuvvetlidir.

Anahtar sözcükler: Dominansi; el kavrama kuvveti; el; eklem tutulumu; romatoid artrit. 
Rheumatoid arthritis (RA) is the most common inflammatory disease in society today. It is chronic, systemic, and painful, and the symmetrical involvement of the peripheral joints leads to deformation and progressive joint destruction. ${ }^{[1]}$

The hand represents the earliest affected joint in RA. Wrist involvement occurs most often (70-90\%), but RA can also be found in the metacarpophalangeal joints (MCPJs) and proximal interphalangeal joints (PIPJs). ${ }^{[2]}$ The effect of RA in the joints ranges from minor damage and functional impairment to severe destructive arthritis with significant disability. ${ }^{[3]}$ In the majority of patients, this is due to joint involvement leading to limitations in range of motion (ROM), joint deformities, and muscle atrophy. ${ }^{[4,5]}$

Persistent synovitis and the development of bone erosion are typical features of RA, with the synovitis being defined symmetrically in the hand and foot joints. This definition is also included in the American College of Rheumatology (ACR) classification criteria. Although symmetrical joint involvement is widely accepted, it has been reported in some studies that inflammation increases due to trauma and excessive activity, and as a result, the findings in the dominant hand are likely to be more severe than in the non-dominant hand. ${ }^{[6-8]}$ In line with this and in view of the asymmetrical and unilateral involvement in patients with chronic neurological diseases (i.e., poliomyelitis, meningioma, encephalitis, and neurovascular syphilis) along with the study results that indicated preserved limb paralysis, it can be concluded that symmetrical involvement of joints does not always occur with RA ${ }^{[9]}$ In fact, this aspect has been clarified in the literature in which the anti-inflammatory effects of physical rest and immobilization were noted. ${ }^{[10,11]}$ However, there are other studies that have reported no difference between the two hands. ${ }^{[12,13]}$

Because of these conflicting results concerning symmetrical involvement, our aim was to evaluate whether hand dominance in patients with RA is related to the clinical/radiological involvement of the hand and hand dexterity.

\section{PATIENTS AND METHODS}

Two hundred and forty-nine patients (238 females, 11 males; mean age $53.02 \pm 11.76$ years; range 25 to 78 years) with right-hand dominance who were diagnosed with RA according to the ACR classification criteria were included in the study, and informed written consent was obtained from each participant. The study was also approved by the local ethics board and was performed in accordance with the principles of the Declaration of Helsinki.

Patients with left-hand dominance or a history of previous hand and/or wrist trauma were excluded from the study along with those who were bedridden according to the Steinbrocker functional staging classification system (Stage IV) and those with bone and/or joint involvement due to neurological, metabolic, or endocrine disease.

The patients' demographic characteristics, such as age, gender, education, marital status, and job status were recorded as well as their disease features (duration of disease, number of tender and swollen joints, and disease stage according to the Steinbrocker functional staging classification system) and their general health assessment (GHA) levels. Each patient also underwent a laboratory test to obtain the erythrocyte sedimentation rate (ESR) $(\mathrm{mm} / \mathrm{h})$, C-reactive protein (CRP) $(\mathrm{mg} / \mathrm{L})$, and rheumatoid factor (RF) (IU/mL) levels. In addition, the disease activity score 28 (DAS 28) was calculated by using the number of tender and swollen joints, ESR, and GHA.

To evaluate the hand and wrist involvement of the patients, the ROM of the wrist, MCPJs, and PIPJs was measured via goniometry.

The results for the wrist were obtained by performing separate tests to determine whether there was ROM limitation was present with regard to flexion and extension. Measurements of $<80^{\circ}$ and $<70^{\circ}$ respectively indicated limited ROM. The results for the MCPJs and PIPJs were evaluated according to the total ROM, which is the sum of the flexion and extension ROM. Measurements of $<135^{\circ}$ and $<100^{\circ}$ respectively indicated limited ROM.

Additionally, deformities such as joint subluxation and dislocation, which are common in RA, were noted, and the presence of nodules, tendinitis, and tenosynovitis was also recorded. The results were then labeled as "present" or "absent", and the number of affected fingers was documented.

Hand dexterity was evaluated using the nine-hole peg test (NHPT), the patients' grip capability for six basic grip types, and their grip strength. The NHPT consists of a block with nine holes in which the subject has to place nine accompanying pegs. The subject is 
scored based on the amount of time (in seconds) that it takes to place and remove all nine pegs.

To assess grip type capability, the six hand grip types that were described by Schlesinger ${ }^{[14]}$ the spherical, cylindrical, and hook grips used for grasping large objects as well as the lateral, palmar, and fingertip grips used for grasping small objects were examined. The results were recorded as "no difficulty", "some difficulty", or "not capable" based on how well they completed the task and the condition of both of their hands.

Power grip strength was measured by a Jamar hand dynamometer (Baseline hydraulic hand dynamometer, Irvington, NY, USA) with the hand semipronated. The patients were seated and the elbow, upper wrist, and thumb had $90^{\circ}$ flexion. Pinch strengths were assessed by a pinch meter (Baseline hydraulic pinch gauge, Irvington, NY, USA) in the lateral, palmar, and fingertip positions, and measurements were performed three times consecutively, with the mean values being recorded in kilograms.

Additionally, the Larsen score was calculated in the radiological evaluation, and the following 15 joints were evaluated: the four quadrants, six MCPJs, and four PIPJs of each wrist along with the interphalangeal joint (IPJ) of the two thumbs. Each joint was scored on a scale ranging from $0-5$, and a total score for each patient ranging from $0-70$ was then obtained.

All of these parameters were evaluated separately for the left (non-dominant) and right (dominant) hand, and the results were subsequently compared.

\section{Statistical analysis}

Data analysis was done using the SPSS version 11.5 for Windows software program (SPSS Inc., Chicago, IL, USA), and the continuous variables were evaluated with the Shapiro-Wilk test to determine whether they differed from the normal distribution. Chi-square tests were used to compare descriptive statistics, and the results were given as mean \pm standard deviation for continuous variables and frequencies and percentages (\%) for nominal variables. Statistically significant differences between the groups related to normally distributed continuous variables were identified via Student's t-test for dependent groups, whereas the significance of difference in terms of normal undistorted continuous variables was performed using the Wilcoxon rank sum test for independent groups. Furthermore, the significance of difference for nominal variables was analyzed using Pearson's chi-square test. The Pearson (normally distributed continuous variables) and Spearman (normal undistorted continuous variables) correlation coefficients were performed for those correlations deemed to be significant. Values of $\mathrm{p}<0.05$ were considered to be statistically significant.

\section{RESULTS}

The mean disease duration in patients was 15.00 $(18.60 \pm 14.39)$ years, and the demographics distribution and disease characteristics along with the laboratory parameters of the patients are shown in Table 1.

The comparisons and distributions of the RA-induced findings according to the right and left hands, including ROM limitations, deformities, nodules, tendinitis, and tenosynovitis are shown in Table 2.

Table 1. Distribution of demographic and disease characteristics along with the laboratory parameters of the patients $(n=249)$

\begin{tabular}{|c|c|c|c|}
\hline Parameters & $\mathrm{n}$ & $\%$ & Mean \pm SD \\
\hline Age (years) & & & $53.0 \pm 11.8$ \\
\hline \multicolumn{4}{|l|}{ Gender } \\
\hline Female & 238 & 95.6 & \\
\hline Male & 11 & 4.4 & \\
\hline \multicolumn{4}{|l|}{ Education duration } \\
\hline$\leq 5$ years & 215 & 86.3 & \\
\hline$>5$ years & 34 & 13.7 & \\
\hline \multicolumn{4}{|l|}{ Marital status } \\
\hline Married & 202 & 81.1 & \\
\hline Single & 33 & 13.3 & \\
\hline Widowed/divorced & 14 & 5.6 & \\
\hline \multicolumn{4}{|l|}{ Employment } \\
\hline Housewife & 236 & 94.8 & \\
\hline Blue-collar worker & 4 & 1.6 & \\
\hline White-collar worker & 9 & 3.6 & \\
\hline Disease duration (years) & & & $18.60 \pm 14.39$ \\
\hline Steinbrocker stage (I-IV) & & & $1.97 \pm 0.36$ \\
\hline Number of tender joints & & & $8.97 \pm 8.35$ \\
\hline Number of swollen joints & & & $2.75 \pm 3.14$ \\
\hline \multicolumn{4}{|l|}{ General health assessment } \\
\hline$(0-100 \mathrm{~mm})$ & & & $46.38 \pm 27.27$ \\
\hline \multicolumn{4}{|l|}{ Erythrocyte sedimentation } \\
\hline \multicolumn{4}{|l|}{ Rheumatoid factor } \\
\hline level (IU/mL) & & & $115.17 \pm 193.10$ \\
\hline \multicolumn{4}{|l|}{ C-reactive protein } \\
\hline level $(\mathrm{mg} / \mathrm{L})$ & & & $13.00 \pm 17.14$ \\
\hline \multicolumn{4}{|l|}{ Disease activity score } \\
\hline 28 level & & & $4.57 \pm 1.52$ \\
\hline
\end{tabular}




\begin{tabular}{|c|c|c|c|c|c|c|c|c|c|c|c|}
\hline & \multicolumn{5}{|c|}{ Right upper extremity } & \multicolumn{5}{|c|}{ Left upper extremity } & \multirow[b]{2}{*}{$p$} \\
\hline & $\mathrm{n}$ & $\%$ & Median & Min.-max. & Mean \pm SD & $\mathrm{n}$ & $\%$ & Median & Min.-max. & Mean \pm SD & \\
\hline \multicolumn{12}{|l|}{ Wrist flexion ROM } \\
\hline limitation & 141 & 56.6 & & & & 124 & 49.8 & & & & 0.003 \\
\hline \multicolumn{12}{|l|}{ Wrist extension ROM } \\
\hline limitation & 205 & 82.3 & & & & 188 & 75.5 & & & & $0.003 \mathrm{~g}$ \\
\hline MCPJ ROM limitation & 158 & 63.5 & & & & 151 & 60.6 & & & & 0.812 \\
\hline The number of limited joints & & & & & $1.97 \pm 1.34$ & & & & & $1.82 \pm 1.29$ & 0.189 \\
\hline \multicolumn{12}{|l|}{ PIPJ ROM limitation } \\
\hline (not belonging to any deformity) & 104 & 41.8 & & & 79 & 31.7 & & & & 0.0019 & \\
\hline The number of limited joints & & & & & $1.68 \pm 1.58$ & & & & & $1.52 \pm 1.53$ & 0.0019 \\
\hline MCPJ subluxation & 79 & 31.7 & & & & 71 & 28.5 & & & & 0.2779 \\
\hline The number of subluxated joints & & & & & $0.63 \pm 1.18$ & & & & & $0.59 \pm 1.22$ & 0.286 \\
\hline Piano key sign & 61 & 24.5 & & & & 45 & 18.1 & & & & 0.037 \\
\hline Ulnar deviation & 82 & 32.9 & & & & 79 & 31.7 & & & & 0.459 \\
\hline The number of deviated joints & & & 0.0 & $0.0-4.0$ & $0.52 \pm 0.97$ & & & 0.0 & $0.0-4.0$ & $0.49 \pm 0.89$ & $0.272^{*}$ \\
\hline Boutonniere deformity & 124 & 49.8 & & & & 104 & 41.8 & & & & 0.0019 \\
\hline The number of deformed joints & & & 0.0 & $0.0-5.0$ & $0.92 \pm 1.10$ & & & 0.0 & $0.0-4.0$ & $0.78 \pm 1.08$ & $0.001^{*}$ \\
\hline Swan neck deformity & 145 & 58.2 & & & & 143 & 57.4 & & & & 0.213 \\
\hline The number of deformed joints & & & 0.0 & $0.0-5.0$ & $1.24 \pm 1.22$ & & & 0.0 & $0.0-5.0$ & $1.18 \pm 1.22$ & $0.132^{*}$ \\
\hline $\mathrm{Z}$ deformity of the thumb & 78 & 31.3 & & & & 71 & 28.5 & & & & 0.3549 \\
\hline Nodules & 24 & 9.6 & & & & 18 & 7.2 & & & & $0.054 \mathrm{~g}$ \\
\hline Interosseous atrophy & 154 & 61.8 & & & & 155 & 62.2 & & & & 0.7829 \\
\hline Hypertrophic degeneration & 83 & 33.3 & & & & 82 & 32.9 & & & & 0.740 \\
\hline De Quervain's tendinitis & 2 & 0.8 & & & & 2 & 0.8 & & & & $1.000 \mathrm{~g}$ \\
\hline Trigger finger & 4 & 1.6 & & & & 2 & 0.8 & & & & 0.318 \\
\hline Dupuytren's contracture & 35 & 14.1 & & & & 29 & 11.6 & & & & 0.109 g \\
\hline
\end{tabular}

Significant limitations were found in the right hand compared with the left regarding wrist flexion and extension ( $\mathrm{p}=0.003, \mathrm{r}=0.617 ; \mathrm{p}=0.003$, $\mathrm{r}=0.742$, respectively), the total number of PIPJs $(\mathrm{p}=0.001, \mathrm{r}=0.880)$, and the number of affected PIPJs $(p=0.001, r=0.513)$. In terms of the piano key sign, boutonniere deformity, and number of fingers with this deformity, the right hand had significantly higher figures than the left $(p=0.037$, $\mathrm{r}=0.582 ; \mathrm{p}=0.001, \mathrm{r}=0.837 ; \mathrm{p}=0.001, \mathrm{r}=0.421$, respectively).

The mean duration for the NHPT was 34.50 $(33.81 \pm 12.60)$ seconds for the right hand and $41.00(43.30 \pm 12.84)$ seconds for the left hand, but the difference was not statistically significant $(\mathrm{p}=0.053)$.

The distribution of right and left hand grip capability with regard to the six grip types and a comparison of the results are presented in Table 3. However, no significant differences were found ( $\mathrm{p}>0.05)$.

Furthermore, the distribution of grip strength in the two hands and a comparison of the results are shown in Table 4. We determined that the right hand was significantly stronger than the left in all of the tests (power grip strength: $\mathrm{p}=0.013, \mathrm{r}=0.527$; lateral grip strength: $\mathrm{p}=0.027, \mathrm{r}=0.378$; palmar grip strength: $\mathrm{p}=0.034, \mathrm{r}=0.287$; and fingertip grip strength: $\mathrm{p}=0.041, \mathrm{r}=0.385)$.

According to the evaluation of the patients on the basis of the Larsen score, the mean score was $39.50(43.49 \pm 23.59)$ in the right hand and 32.00 $(41.66 \pm 20.78)$ in the left hand. This difference was statistically significant in favor of the right hand $(\mathrm{p}=0.031, \mathrm{r}=0.164)$. 


\begin{tabular}{|c|c|c|c|c|c|}
\hline \multirow[t]{2}{*}{ Grip type } & \multicolumn{2}{|c|}{ Right hand } & \multicolumn{2}{|c|}{ Left hand } & \multirow[b]{2}{*}{$p$} \\
\hline & $\mathrm{n}$ & $\%$ & $\mathrm{n}$ & $\%$ & \\
\hline \multicolumn{6}{|c|}{ Cylindrical grip type } \\
\hline No difficulty & 185 & 74.3 & 189 & 75.9 & \multirow{3}{*}{$0.207 *$} \\
\hline Some difficulty & 57 & 22.9 & 53 & 21.3 & \\
\hline Not capable & 7 & 2.8 & 7 & 2.8 & \\
\hline \multicolumn{6}{|l|}{ Spherical grip type } \\
\hline No difficulty & 195 & 78.3 & 201 & 80.7 & \multirow{3}{*}{$0.318 *$} \\
\hline Some difficulty & 49 & 19.7 & 40 & 16.1 & \\
\hline Not capable & 5 & 2.0 & 8 & 3.2 & \\
\hline \multicolumn{6}{|l|}{ Hook grip type } \\
\hline No difficulty & 204 & 81.9 & 209 & 83.9 & \multirow{3}{*}{$0.109 *$} \\
\hline Some difficulty & 38 & 15.3 & 34 & 13.7 & \\
\hline Not capable & 7 & 2.8 & 6 & 2.4 & \\
\hline \multicolumn{6}{|l|}{ Lateral grip type } \\
\hline No difficulty & 171 & 68.7 & 174 & 69.9 & \multirow{3}{*}{$0.451 *$} \\
\hline Some difficulty & 65 & 26.1 & 63 & 25.3 & \\
\hline Not capable & 13 & 5.2 & 12 & 4.8 & \\
\hline \multicolumn{6}{|l|}{ Palmar grip type } \\
\hline No difficulty & 169 & 67.9 & 171 & 68.7 & \multirow{3}{*}{$1.000 *$} \\
\hline Some difficulty & 62 & 24.9 & 59 & 23.7 & \\
\hline Not capable & 18 & 7.2 & 19 & 7.6 & \\
\hline \multicolumn{6}{|l|}{ Fingertip grip type } \\
\hline No difficulty & 160 & 60.2 & 174 & 69.9 & \multirow{3}{*}{$0.053 *$} \\
\hline Some difficulty & 66 & 30.6 & 64 & 25.7 & \\
\hline Not capable & 23 & 9.2 & 11 & 4.4 & \\
\hline
\end{tabular}

Table 4. The distribution of grip strengths of the right and left hands and a comparison of the results

\begin{tabular}{lcccccccc}
\hline & \multicolumn{3}{c}{ Right } & & \multicolumn{3}{c}{ Left } \\
\cline { 2 - 4 } & Median & Min.-max. & Mean \pm SD & & Median & Min.-max. & Mean \pm SD \\
\hline Power grip strength (kg) & 9.64 & $0.0-30.84$ & $10.08 \pm 6.69$ & & 8.31 & $0.0-27.21$ & $8.85 \pm 6.09$ & $0.018^{*}$ \\
Lateral grip strength (kg) & 3.90 & $0.0-9.66$ & $3.64 \pm 2.32$ & & 3.71 & $0.0-9.25$ & $3.45 \pm 2.21$ & $0.026^{*}$ \\
Palmar grip strength (kg) & 3.44 & $0.0-8.30$ & $2.89 \pm 1.97$ & & 2.99 & $0.0-7.98$ & $2.71 \pm 1.89$ & 0.032 \\
Fingertip grip strength (kg) & 2.30 & $0.0-5.44$ & $2.26 \pm 1.53$ & & 2.04 & $0.0-4.80$ & $1.81 \pm 1.43$ & 0.041 \\
\hline Min.: Minimum; Max.: Maximum; SD: Standard deviation; ${ }^{*}$ Wilcoxon rank sum test. & & & & &
\end{tabular}

\section{DISCUSSION}

In our study, we aimed to evaluate whether right-hand dominancy in patients with RA was related to the clinical/radiological involvement of the hand and hand dexterity. Our results showed that ROM limitations associated with wrist flexion and extension along with the total number of PIPJs as well as the presence of piano key sign and boutonniere deformity were more commonly observed in the right hand. In the assessment of grip and pinch strengths, the right hand was stronger than the left, but there was no difference between the hands regarding their grip type capability. Furthermore, the radiological evaluation findings in the right hand were more destructive than in the left. 
Rheumatoid arthritis (RA) is a progressive disease that leads to joint destruction and deformities, and joint ROM is affected from the first years of the disease. ${ }^{[1,15]}$ Previous studies have revealed that the earliest erosions occur in the second and third MCPJs followed by the wrist joint. ${ }^{[16,17]}$ It has also been reported that finger joint involvement was observed less often than other joint involvements. To our knowledge, no similar study exists in the literature that has evaluated ROM limitation. Adams et al. ${ }^{[13]}$ studied the hand involvement of 119 patients who had been diagnosed with RA for less than five years and reported that the limited wrist ROM in the dominant hand was greater than that of the non-dominant hand. They did not evaluate flexion and extension ROM separately but calculated them by combining the total ROM. As in our study, no difference was determined with regard to MCPJ involvement, and they did not evaluate PIPJ involvement independently.

In our study, it was found that the ROM limitations related to wrist flexion and extension together with the PIPJs were much greater in the dominant hand, but MCPJ involvement was similar in both hands. As reported in the literature, MCPJ involvement occurs in the early stages; therfore, since the patients in this study had an average disease duration of 15 years, our results were expected. ${ }^{[16,17]}$ In addition, it has been hypothesized that involvement of joints like the wrist and PIPJs is due to longer disease duration.

In the literature, the studies that have compared both hands in terms of joint deformity, tenosynovitis, and nodules in RA have reported conflicting results. While some reported no differences between the hands, ${ }^{[12,13,18]}$ others found that these conditions associated with RA were seen more frequently in the dominant hand. ${ }^{[18,19]}$ One reason for the dissimilar results is that different deformities have been evaluated, and various methods have been used in the assessment process. In two studies similar to ours, ${ }^{[6,18]}$ both hands were compared in terms of boutonniere and swan neck deformities, ulnar deviation, and flexor tenosynovitis, and no differences was seen between the hands.

Greater deformity was observed in the right hand than left hand in our study with regard to piano key sign and boutonniere deformity, and no differences were detected concerning swan neck deformity, ulnar deviation, $Z$ deformity, tenosynovitis, interosseous atrophy, or hypertrophic degeneration.
Piano key sign is a characteristic of caput ulna syndrome, which is caused by distal radioulnar joint instability and ulnar head subluxation. Wrist involvement in RA often begins with the ulnar side and also affects the extensor tendons in later stages of the disease. ${ }^{[20]}$

In our study, the greater occurrence of wrist ROM limitations and detection of piano key sign in the right hand were evaluated as compatible results because we believe that the reason for the high number of patients with piano key sign was due to greater wrist joint involvement in the dominant hand.

We also discovered that boutonniere deformity occurred more often in the right hand. Swan neck and boutonniere deformities occur in approximately half of the patients with RA. ${ }^{[21]}$ When evaluated separately, the buttonhole deformity has been reported in $36 \%$ of RA patients and swan neck deformity in $14 \%{ }^{[21]}$ Boutonniere deformity occurs especially because of the involvement of the PIPJs, whereas swan neck deformity may include three joint involvements consisting of the MCPJs, PIPJs and distal interphalangeal joints (DIPJs). In our study, PIPJ involvement differed between the two hands, but MCPJ involvement was the same. Boutonniere deformity most likely occurred significantly more in the dominant hand due to the difference in the PIPJ involvement.

In addition, interosseous atrophy and hypertrophic degeneration, both commonly seen in RA, were detected in similar proportions in both hands in our study. There have been reports that interosseous muscle atrophy results from the pain caused by MCPJ involvement, reflex inhibition after the pain, and non-use of the hand. ${ }^{[22,23]}$ Hypertrophic degeneration occurs as a result of chronic synovitis of the MCPJ, but we identified no significant difference in terms of ROM limitation and subluxation of the MCPJ. Therefore, we believe that our result is consistent with other study results concerning this issue.

In addition, we detected no differences between the right and left hands regarding the presence of tenosynovitis and nodules, which corresponds to other results that have been previously reported in the literature. ${ }^{[6,18]}$ We do not believe that this occurred because tenosynovitis and nodules are established deformities but because the change in deformities depends on the effectiveness of treatment. In fact, there are reports in which the appearance of tenosynovitis and nodules was 
reduced, and changes took place based on the treatment received. ${ }^{[24,25]}$

We used the NHPT as one of the assessment tools in this study. In the literature, the NHPT has rarely been used to evaluate the differences associated with hand dominance, but it has been frequently used to assess grip strength. The only study that used the NHPT for evaluative purposes was conducted by Adams et al. ${ }^{[13]}$ who found no difference in terms of hand dexterity between the right and left hands in 119 patients with early RA. They also compared the right and left hands in terms of power grip strength but again found no significant difference was reported. Other studies in the literature have also failed to find any differences related to power grip strength, but the dominant hand strength has been reported to be higher numerically. ${ }^{[8,26]}$

According to studies in which the grip strength of both hands of healthy subjects was evaluated, the dominant hand was $10 \%$ stronger, ${ }^{[27,28]}$ and we also found that the dominant hand was significantly stronger with regard to both power grip strength and pinch strength. However, the difference in the strength between the hands was less than $10 \%$. In addition, strength levels were higher in the dominant hand in our study, though at lower levels than has been reported for healthy people. Our results were reasonable because our patients had different profiles compared with those in previous studies (number, gender, sociocultural status, disease activity level, medications used) and because of the different compensatory mechanisms that were implemented. In our opinion, more comprehensive and wide-scale studies are needed in order to clarify this issue. Furthermore, since to our knowledge no other study has focused on grip type capability, we had no way to compare our findings.

While there are many studies in the literature that have compared the hands in terms of radiological involvement, the reported results are conflicting. This could be because a variety of different evaluation methods have been used in previous studies, such as standard radiography and bone mineral density (BMD). ${ }^{[7,8,18,29]}$ In the studies that used the Larsen score, it was noted that the dominant hand had more joint space narrowing and erosion compared with the non-dominant hand, which was similar to our findings..$^{[7,8]}$ However, in one of his studies, Luukkainen ${ }^{[30]}$ evaluated the radiological difference between the hands of each patient with early RA and found no greater difference in destruction level in the dominant hand. In our study, more radiological damage was detected in the dominant hand, but this can be attributed to the fact that since our patients had an average disease duration of 15 years, the difference between the hands was more significant.

\section{Conclusion}

In this study, greater joint limitation, radiological damage, and deformity were detected in the dominant hand of the patients with RA. This result supports the idea that overuse of the hand and trauma increases joint damage in patients with RA. Despite these results, the dominant hand is still stronger with respect to grip strength (though not to the extent of the healthy subjects), and there is no difference between the hands in terms of grip capability. Thus, factors other than joint involvement are believed to affect the formation of grip strength and grip capability. However, more comprehensive and wide-scale studies are needed in order to clarify the reasons for these results.

\section{Declaration of conflicting interests}

The authors declared no conflicts of interest with respect to the authorship and/or publication of this article.

\section{Funding}

The authors received no financial support for the research and/or authorship of this article.

\section{REFERENCES}

1. Calguneri M. Rheumatoid arthritis. In: Yasavul U, editor. Textbook of internal medicine, Hacettepe University, Ankara: Prestij Press; 2003. p. 1477-95.

2. Isaacs JD, Moreland LW. Clinical features. In: Isaacs JD, Moreland LW, editors. Rheumatoid arthritis. 1st ed. İstanbul: And Press; 2003. p. 36-48.

3. Scott DL, Symmons DP, Coulton BL, Popert AJ. Longterm outcome of treating rheumatoid arthritis: results after 20 years. Lancet 1987;1:1108-11.

4. Rajagopalan A, Burne JA. Stretch reflexes and joint dynamics in rheumatoid arthritis. Exp Brain Res 2010;201:37-45.

5. Horsten NC, Ursum J, Roorda LD, van Schaardenburg D, Dekker J, Hoeksma AF. Prevalence of hand symptoms, impairments and activity limitations in rheumatoid arthritis in relation to disease duration. J Rehabil Med 2010;42:916-21. 
6. Boonsaner K, Louthrenoo W, Meyer S, Schumacher HR Jr. Effect of dominancy on severity in rheumatoid arthritis. Br J Rheumatol 1992;31:77-80.

7. Möttönen TT. Prediction of erosiveness and rate of development of new erosions in early rheumatoid arthritis. Ann Rheum Dis 1988;47:648-53.

8. Owsianik WD, Kundi A, Whitehead JN, Kraag GR, Goldsmith C. Radiological articular involvement in the dominant hand in rheumatoid arthritis. Ann Rheum Dis 1980;39:508-10.

9. Thompson M, Bywaters EG. Unilateral rheumatoid arthritis following hemiplegia. Ann Rheum Dis 1962;21:370-7.

10. Lee P, Kennedy AC, Anderson J, Buchanan WW. Benefits of hospitalization in rheumatoid arthritis. Q J Med 1974;43:205-14.

11. Glynn JJ, Clayton ML. Sparing effect of hemiplegia on tophaceous gout. Ann Rheum Dis 1976;35:534-5.

12. Akcay S, Eksioglu E, Suvardar F, Cevikol A, Ergin M. The effect of dominancy on rheumatoid arthritis patients' hands. Journal of Arthroplasty Arthroscopic Surgery 1996;7:32-4.

13. Adams A, Burridge J, Hammond A, Cooper C. The effects of early rheumatoid arthritis on dominant and non-dominant hand impairment and function. Br J Hand Therapy 2005;10:93-9.

14. Schlesinger G. Der Mechanische aufbau der künstlichen glieder. In: Borchardt $M$, editor. Ersatzglieder und arbeitshilfen für kriegsbeschädigte und unfallverletzte. Berlin: Springer-Verlag; 1919. p. 321-661.

15. Melvin J. Rheumatoid disease in the adult and child: Occupational therapy and rehabilitation. 3rd ed. Philadelphia: Fa Davis Co; 1989. p. 357-75.

16. Martel W, Hayes JT, Duff IF. The pattern of bone erosion in the hand and wrist in rheumatoid arthritis. Radiology 1965;84:204-14.

17. Maritz NG, Gerber AJ, Greyling SJ, Sandra BB. A radiological study of the rheumatoid hand in black South Africans. S Afr Med J 2005;95:795-7.

18. Mody GM, Meyers OL, Reinach SG. Handedness and deformities, radiographic changes, and function of the hand in rheumatoid arthritis. Ann Rheum Dis 1989;48:104-7.
19. Sollermann C. The hand. In: Firestien GS, Panayi G, Wollheim FE, editors. Rheumatoid arthritis: New frontiers in pathogenesis and treatment. 1st ed. Oxford: Oxford University Press; 2000. p. 467-76.

20. Jensen CM. Synovectomy with resection of the distal ulna in rheumatoid arthritis of the wrist. Acta Orthop Scand 1983;54:754-9.

21. Boyer MI, Gelberman RH. Operative correction of swanneck and boutonniere deformities in the rheumatoid hand. J Am Acad Orthop Surg 1999;7:92-100.

22. Eberhardt K, Johnson PM, Rydgren L. The occurrence and significance of hand deformities in early rheumatoid arthritis. Br J Rheumatol 1991;30:211-3.

23. Swezey RL, Fiegenberg DS. Inappropriate intrinsic muscle action in the rheumatoid hand. Ann Rheum Dis 1971;30:619-25.

24. Karakose S, Ozerbil OM, Tarhan S, Tureli OC, Sendur OF. Efficacy of ultrasonography in diagnosis and follow-up assessment of patients with rheumatoid arthritis. J Med Sci 1996;16:370-3.

25. Scrivo R, Spadaro A, Iagnocco A, Valesini G. Appearance of rheumatoid nodules following anti-tumor necrosis factor alpha treatment with adalimumab for rheumatoid arthritis. Clin Exp Rheumatol 2007;25:117.

26. Madenci E, Gursoy S. Hand deformity in rheumatoid arthritis and its impact on the quality of life. Pain Clin 2003;15:255-60.

27. Lunde BK, Brewer WD, Garcia PA. Grip strength of college women. Arch Phys Med Rehabil 1972;53:491-3.

28. Swanson AB, Matev IB, de Groot G. The strength of the hand. Bull Prosthet Res 1970;10:145-53.

29. Deodhar AA, Brabyn J, Jones PW, Davis MJ, Woolf AD. Measurement of hand bone mineral content by dual energy x-ray absorptiometry: development of the method, and its application in normal volunteers and in patients with rheumatoid arthritis. Ann Rheum Dis 1994;53:685-90.

30. Luukkainen R, Kaarela K, Isomäki H, Kiviniemi P. Relationship between clinical synovitis and radiological destruction, in rheumatoid arthritis. Clin Rheumatol 1983;2:223-6. 